\title{
Italian Lifelong Learning in Europe: Notes to the Second Millennium
}

\author{
Simona Savelli \\ Facoltà di Scienze della Formazione, Università degli Studi Guglielmo Marconi, Italia, Roma \\ Correspondence: Simona Savelli, Via Roberto Ardigò 4, 35031 Abano Terme, Padova, Italia
}

\author{
Received: December 5, 2013 Accepted: December 19, 2013 Online Published: January 24, 2014 \\ doi:10.11114/jets.v2i2.303 \\ URL: http://dx.doi.org/10.11114/jets.v2i2.303
}

\begin{abstract}
In Italy the Education and Training System is undergoing a period of complex reorganization. This occurs within a European Integration Process aimed at achieving a full Citizenship right and the maximum mobility among Member States. Starting from the latest European Directives, which make the concept of Competence the cornerstone of Education, Training and Work, and examining data from some very recent surveys of national and international significance, here we propose a picture of the current Italian situation.
\end{abstract}

Keywords: competence, education, Europe, Italy, learning, training

\section{Introduction}

The development of the the individual, the society and the economy: these are the goals that the European Union entrusts to the Education and Training System in 2001. In effect, in a System working properly, the individual can develop and lead a decent standard of living, society can reduce inequalities and manifest itself in the plural and the economy can provide a happy synthesis between technology and business.

Today more than ever, the Education and Training System has to deal with social change, relating to the duration of life and the nature of that life, to social and linguistic diversity and the nature of that diversity, to the mutation of the labor system, whereby the nature of work changes and changes the way of understanding job competence.

To everyone and always, the System has to ensure equal opportunities to participate actively in the economic and social life and not to suffer the changes constantly taking place in our society.

Is it possible to achieve goals such as these? In this regard, the European Union (EU) relies on three key concepts: access, effectiveness, connection.

An individual can have easier access to a Learning System when the system is concerned to guide and advise its users, to provide a custom path, to make life easier by offering a greater flexibility to the needs of the families, to recognize personal experiences that acquire a professional value and professional experiences that acquire an educational value, to make everyone able to take advantage of multimedia environments, to welcome each person using age-appropriate manner and to provide a differentiated work-study overview.

An effective Education and Training System must provide basic literacy to its users, must constantly update teachers, users and trainers, must ensure access to multimedia learning environments and must be monitored to guarantee work quality.

At last, to work properly the Education and Training System should be connected to the world of work, research, enterprise, in a context of international mobility and in cooperation with all the Member States of the European Union.

\section{A Permanently Integrated Learning}

In modern complex societies characterized by constant change, the Teaching-Learning process responds to the fundamental human need to create and use knowledge in order to dominate effectively technological development and globalization processes. In this context, learning declines as a potential achievable throughout life and in a variety of situations.

Therefore the European Union often points out the concept of Right of Citizenship. Being citizens today means to manage dynamically a life project and acquire, maintain and develop, knowledge, abilities and competences (Alberici, 
2002) (Note 1). The exercise of this Right is itself a factor of individual growth, because it allows effective attribution of meaning and active participation in socio-cultural dynamics, but at the same time it is a factor of social cohesion and it impacts within the working environment, both as regards the development of human resources, as for what concerns the economic production.

The conception of a Teaching-Learning Process as integrated has many consequences, both theoretically, and practically. For example, the concept of Adulthood is revised and rethought, responding to a more flexible definition to which contribute several factors: biological-chronological and legal, but also social and psychological. Learning then, is not only identified by the concept of activity, but it means at the same time development potential; it takes advantage of all the components: cognitive, emotional, professional, experiential, contextual and it responds to individual differences of time, place, styles, speed (Di Nubila, 2005) (Note 2).

To be truly integrated, scholastic, working and experiential learning require a Recognition System that ports on the same floor formal learning, non-formal learning and informal learning.

In line with the above, there are many authors that highlight the importance of the Experiential Factor. Di Nubila for example, recalls that moving with method in the Teaching-Learning Process means to facilitate the organization of a System of Relationships among three sets of structures: the cognitive and experiential structure of the learner, the structure of knowledge and learning to acquire, the set of operations to be implemented in the practice of Education (Di Nubila, 2005) (Note 3).

In effect, the relationship of each of us with knowledge revolves around the basic concepts of meaningful event, experience and competence: the events that we consider to be significant go to constitute our knowledge, at events deemed to be significant we live our practical experiences and while processing these experiences, we build our competences.

\section{The Logic of Competences}

The competence, moment of passage between knowledge and action, that requires personal reprocessing in a context, collects a large inheritance of studies (Di Nubila, 2005) (Note 4) and declensions (Di Nubila, 2005) (Note 5).

Currently, the worlds of Education, Training and Work are connected in the Logic of Competences, where Competence is taking the role of a cognitive, organizational, regulatory and legal tool.

At a European and International level, competence is considered the key resource for development and the essential prerequisite for any job performance. As a combination of knowledge, skills and attitudes, appropriate to the context, competences are officially elected at the heart of the European System of Education and Training in 2006. Among them eight key competences for lifelong learning are identified: those competences that every individual needs for his personal fulfillment and development, for active citizenship, social inclusion and employment. To these, some cross-cutting factors are added (Table 1).

Table 1. Key Competences and Cross-Cutting Factors for Lifelong Learning (UE, 2006).

\section{KEY COMPETENCES}

Communication in the Mother Tongue, Communication in Foreign Languages, Mathematical Competence and Basic Competences in Science and Technology, Digital Competence, Competence in Learning to Learn, Social and Civic Competences, Sense of Initiative and Entrepreneurship, Cultural Awareness and Expression

\section{CROSS-CUTTING FACTORS}

Critical Thinking, Creativity, Ability to Solve Problems, Risk Assessment, Decision Making, Constructive Management of Feelings

\section{Notes on Italy}

Since the 90s, there are many Italian legal provisions that operate for the reorganization of the System of Education, Training and Work in the direction of integration and continuity. Among the many measures at the national level, we find: the age rising in Compulsory Education, the introduction of Compulsory Training, the extension of Apprenticeships in all Educational and Vocational Paths, the upgrading of the Educational Offer, the reform of University Courses, the establishment of Interprofessional Funds for Continuing Training, the testing and full implementation of an Adult Education System (Alberici, 2002) (Note 6).

And more, at different territorial levels, we find: the identification of strategic priorities in Adult Education, the definition of general guidelines and criteria for resources' distribution, the definition of criteria and guidelines for the determination of Education and Training Standards, the monitoring and evaluation of the Education and Training Offer, the definition of devices for the certification of paths and the recognition of credits, the promotion of the Training Offer at a local and regional level, the definition of intervention criteria starting from the analysis of the professional and 
training needs of the territories (Alberici, 2002) (Note 7).

In 1997 the Permanent Territorial Centers (CTP) are established. They contribute to the identification of needs, planning, organization and execution of initiatives of Adults' Education and Training at a local level. At the same time Education and Training Booklets or Personal Portfolio of Competences are set up. They collect credits previously recognized and credits resulting from activities carried out in the centers.

In the National Report of 2009, within the European Work Program "Education and Training 2010”, Italy answers to the European Union questions about the implementation of Key Competences. Starting from the analysis of this paper, we illustrate some important lines of development gained in Italy until this time.

\subsection{Competences Offer}

What did Italy since 2006 for developing the provision of key competences?

In 2006 Italy begins to define a National System of minimum professional standards, of recognition and certification of competences and of educational and training standards designed to converge into a National Qualifications Framework (NQF). In 2009, the Guidelines for Minimum Standards of Basic and Transversal Competences According to the Format Expected by the European Qualifications Framework (EQF) are presented (Note 8).

In the period 2007-2013, as a part of the European Cohesion Policy (Note 9) and as a part of the National Operational Programs (NOP) (Note 10), in the Regions Campania, Calabria, Puglia and Sicilia (Note 11), the percentage of young people who drop out of school and of students with limited skills in Reading and Mathematics is monitored, with the aim to reduce these percentages, respectively, from 26 to $10 \%$, from 35 to $20 \%$ and from 48 to $21 \%$.

The NOP "Skills for development" allocates $60 \%$ of resources to the strengthening of Key Competences of pupils and teachers. Within this program, in the years 2007 and 2008, 500 thousand students take advantage of opportunities for further development of Key Competences: in most cases, they are courses and workshops organized outside school hours and offered to groups of students from different classes of all kinds and types of schools.

Laboratories for the development of Basic Competences are designed inside the NOP "Learning environments": in 2008, workshops in Mathematics and Science are carried out in almost 80\% of First Cycle Schools in the Regions Campania, Calabria, Puglia and Sicilia.

\subsection{Competences, Education and Training}

How the eight key competences are inserted within the General Education and the Vocational Education and Training?

Following the European Union Recommendation of 2006, several national legislative measures lead to the definition of learning output in terms of knowledge, skills and competences, valid for the whole of the ten years of Compulsory Education (Note 12). Some Key Competences are included in the National and Regional Curriculum as disciplines that constitute Compulsory Education. The items indicated as Learning Outcomes, covering the entire curriculum of the disciplines, represent the Cultural Axes (Table 2).

Table 2. Learning Outcomes, Disciplines, Cultural Axes for Lifelong Learning (MD 139/2007).

\begin{tabular}{lll}
\hline LEARNING OUTCOMES & DISCIPLINES & CULTURAL AXES \\
\hline Learning to Learn, Plan, Communicate, Participate & Native Language, Foreign Language, Axis of Languages, Mathematical \\
and Cooperate, Act Independently and & Mathematics, Science and Axis, Scientific-Technological Axis, \\
Responsibly, Solve Problems, Identify Linkages & Technology, Digital Competence, Socio-Historical Axis \\
and Relationships, Acquire and Interpret & Civic and Social Skills \\
Information &
\end{tabular}

In Vocational Training, learning outcomes are inserted into the area of Basic and Cultural Competences, to which are added the disciplines and competences of the specific professional field. Correspondences between Cultural Axes and Key Competencies are identified in the context of General Education.

Since the years 2009-2010, the three-years' qualification courses that accomplish the Right-Duty to Education and Training become regulated. The acquisition of Basic Competences at the end of the period of Compulsory Education is similarly expected from Upper Secondary Schools and Vocational Education and Training Paths.

\subsection{Competences and Abandonment}

How young people leaving Initial Education and Training are helped to develop competences to prepare them for adult life?

In the Ministerial Decree 139/2007 is confirmed in ten years the duration of Compulsory Education. This is aimed at achieving a Secondary School Qualification or a Vocational Qualification of at least a three years' duration before the 
age of eighteen.

The guidance function of the two years of Higher Education is enriched with new pedagogical approaches, among which, particularly important are the methodologies based on laboratory and on alternating school and work, starting from fifteen years of age.

It increases the focus on continuous improvement of the Education and Training Offer in the direction of quality and assessment, in order to ensure a minimum level of competences to all young people who drop out of Initial Education.

In 2008, the Minimum Standards of the New Accreditation System for Training Facilities for Services' Quality in Education and Training, acquire:

- as guiding principles: lifelong learning, maintaining controls' effectiveness, requirements simplification and verifiability, controls' integration and synergy;

- as benchmarks: infrastructure and logistics resources, economic and financial reliability, management capacity and professional resources, effectiveness and efficiency, relations with the territory.

It grows and spreads the Italian guide for Self-Evaluation of Educational and Training Facilities (Note 13) and the Methodology of Peer Review (Note 14).

In the Vocational Training System there is a growing attention not only on the overall quality of the training project and organization, but also on the results achieved by students as an indicator of the system impact.

\subsection{Competences and Lifelong Learning}

How is it given to adults the opportunity to develop and update their key competences?

5.4.1 Policies

In this sense, National Policies aim to:

- facilitate reintegration into Education of young people who have turned the sixteenth year of age and who are not in possession of the First Cycle of Education Qualification and/or have not completed Compulsory Education;

- achieve higher levels of Education for adult population, including immigrants, with particular reference to the acquisition/update of Key Competences;

- promote knowledge of Italian Language by immigrants to facilitate their social integration.

In the period 2006-2008, adults courses delivered by the Permanent Territorial Centers (CTP) and the Educational Institutions running evening courses (ISGCS) refer to the priority, and thus to the target groups, mentioned in the 2010 European Program for Education and Training: school age youth who have dropped out of school (aged 16-19), young twenty-two (aged 20-24) without a High School Degree, adults aged between 25 and 64 not included in Education and Training Paths, adults with low education, foreign adults, adult prisoners, unemployed adults and non-employed, employed adults, adults over 65 .

Since 2005, the Citizen's Training Booklet allows to collect-rebuild, organize and document different learning experiences made in Education, Training, Work and daily life and express the results of these experiences in terms of acquired competences.

\subsubsection{Partnerships}

In the years 2008-2009, in order to mitigate the effects of the economic crisis, some legislative provisions, in addition to the allocation of public resources, consider the possibility of complementary interventions by Private Collective Subjects. So:

- Bilateral Bodies (Note 15) can integrate with their own resources, the cost of the extension of the unemployment benefit in favor of productive sectors and subjects who did not previously take advantage of them, such as the apprentices.

- Interprofessional Joint Funds (Note 16) may take extraordinary and exceptional measures.

In 2009, the Framework Agreement on the Reform of Contractual Arrangements assigns to Collective Bargaining the task of defining additional forms of bilaterality for the operation of supplementary services for the welfare state.

In the context of Collective Bargaining, on the occasion of 2007-2008 contract renewals, Social Partners intervene to encourage the spread of on-the-job training by defining a number of hours for workers' participation in learning activities and by promoting training for the development of competences for career progression.

Obstacles to these measures are the poor dissemination of Decentralized Bargaining and the limited presence of 
provisions aimed at enhancing Lifelong Learning (Note 17).

Social Partners have a role in the management of tools supporting Lifelong Learning, both within the Interprofessional Joint Funds, either in the allocation of Regional Resources.

Organizations that promote the establishment of the Joint Funds participate in the definition of the National guidelines of the Observatory for Lifelong Learning (Note 18).

In the years 2006-2008, the Ministry of Education (MIUR) works closely with: the National Agency for the Development of School Autonomy (ANSAS/INDIRE) (Note 19); the National Institute for the Evaluation of the Educational System of Education and Training (INVALSI) (Note 20); the Institute for Workers' Training (ISFOL) (Note 21); the RAI (Italian Radio and Television) (Note 22); the State-Regions Joint Conference (Note 23); Regions and Local Authorities (Provinces and Municipalities), the Regional Education Offices (USR) (Note 24); Social Partners.

\subsubsection{Actions}

In the years 2007-2008 progress has been made from a regulatory standpoint and with regard to the increasing of specific training offers. The Permanent Territorial Centers (CTP) and the Educational Institutions running evening courses (ISGCS) are reorganized and divided into local networks in order to raise the levels of Adult Population Education and Training (Note 25). In the period 2006-2008, significant advances have been made in this direction, with an increasing number of locations, courses, users, qualifications and certificates issued at the end of the courses.

The Continuing Training Initiatives directed to the updating and retraining of employed workers are organized by companies or based on the choices of individual workers. In the first case, training initiatives supported by the Interprofessional Joint Funds have particular development. Entered into service in 2004, they are promoted and created by Organizations representing businesses and workers, on the basis of voluntary contributions paid by Member Companies. In the period 2004-2007, the Interprofessional Joint Funds finance 7 thousand training plans for 900 million Euro, involving 50 thousand companies and 900 thousand workers (Note 26). The predominant subjects of Financed Training Initiatives are Language Knowledge and Competences, Computer Competences and Transversal Competences.

In the second case, the Continuing Training Initiatives financed by Regions through the provision of individual vouchers, intended primarily for workers in small companies, for the over forty-five, for workers with low qualification and Atypical Workers, are especially significant (Note 27). The training offer focuses on Language and Computer Competences and on Competences related to Entrepreneurship and Spirit of Enterprise. Regional Funding amounts to approximately 115 million Euro per year.

Among Mandatory Training Courses, we find: periodic update for specific professional competences and short and medium term training initiatives adopted by the Government as anti-crisis measures, directed toward the recovery of Basic and Transversal Competences, Language Competences and Computer Competences, targeted at workers suspended or expelled from production processes.

In 2009, the European Social Fund, however, is the only means of co-financing in the ordinary way that non-employees workers can use.

Employment Centers represent the privileged interlocutors, with regard to guidance and placement, in more or less structured Training Courses, targeted at the unemployed. Since 2000, they offer to every unemployed citizen an orientation meeting within three months from the beginning of the unemployment state and a proposal for adhesion to job placement initiatives, training or retraining, or other measures that promote professional integration.

\subsubsection{Participation}

While recording significant increases in the levels of schooling and participation of younger age groups, the affluence of adults is limited and at the same time stable.

The propensity to participate in Education and Training Activities is also lower in the case of possession of lower educational qualifications, while it is higher for higher qualifications. This trend is largely confirmed in the different national geographical areas. The level of Education is also binding as regards participation in Continuing Training Activities by workers.

It is a problematic phenomenon in a country where the level of Upper Secondary Education and University is limited (Note 28).

In 2007, the percentage of adults participating in Education and Training Activities amounts to just over 6\%, against the target envisaged by the Lisbon Strategy (Note 29) which aims to reach $12.5 \%$ in 2010 and not less than $15 \%$ in 2020.

In 2006, about 55\% of workers are involved in at least one Training Activity. Unstructured training prevails on 
structured training. The level of participation among public employees is approximately twice that of private workers and self-employed. Within each occupational category then, other marked differences are related to professional classification, socio-demographic characteristics and size of the company: more these values are low, the lower is the opportunity to access training.

5.4.5 Adults' Competences (The PIAAC Program 2008-2013)

In 2008, Italy joins the Program for International Assessment of Adult Competencies (PIAAC 2008-2013) developed by the Organization for Economic Cooperation and Development (OECD). The survey is conducted on the Italian population between 16 and 65 years old in the 2010-2011 period.

The presentation of the results in October 2013 highlights some worrying aspects:

- Literacy Competences are below the average of OECD countries;

- in Literacy Competences, Italy is at the last place on the list;

- in Mathematics Competences, it is second to last in the ranking;

- for all levels of Education considered, the North-South divide is stable, and it is particularly large for University Education levels;

- for the more Advanced Levels of Education, the deficit of our country is particularly evident compared with the OECD average;

- participation in activities of Formal and Informal Learning for Adults is the lowest among OECD countries;

- young people aged between 16 and 29 who do not study and do not work have a particularly low level of Literacy Competences;

- among adults, only one-third of the employed reaches a level of Literacy Competences considered to be the minimum necessary to live and work in the twenty-first century, with significant differences at the local level.

But there are also some positive aspects:

- the decreasing percentage of population at the lower levels of competence;

- in Literacy Competences, the reduction of the gap between the age group 16-24 and the age group 55-64, with an improvement of the more mature band;

- in Literacy Competences, the contraction of the gap with the OECD average;

- an overall improvement compared with the findings of recent years (Note 30).

5.5 Competences and Teachers

How do teachers and trainers are trained in the adoption of a competence-based approach?

The Ministry of Education promotes the implementation of projects on Peer Learning of Basic Competences created by State Education System and Regional Vocational Training System operators, addressing In-Service Teachers.

In the period 2007-2013 within the National Operational Programs (NOP) and the European Cohesion Policies, Training Initiatives aimed at In-Service Teachers on the teaching of Key Competences include:

- Projects proposed and implemented by individual Schools and planned in accordance with the Educational Curricular Offer of the institution;

- Educational Initiatives proposed at the central level through the National Training Programs "Basic Learning" developed by the Ministry of Education in collaboration with the ANSAS/INDIRE (Note 31).

The NOP "Competences for Development" strengthens this last proposal.

Within the School-NOP, INVALSI implements an information campaign to raise awareness on OECD-PISA surveys (Note 32) on Key Competences for Teachers of Italian, Mathematics and Science in the first two years of Upper Secondary School. In Campania, Calabria, Puglia and Sicilia Regions there is a participation of more than $70 \%$ of the recipients' teachers. A specific campaign on the same topics is implemented in favor of the Headmasters of Lower Secondary Schools and provides information seminars on all international surveys on student competences (OECD and IEA (Note 33)).

In the school year 2009/2010, a training initiative on the assessment of key competences aimed at First Cycle Secondary Schools' teachers is expected.

In the school years 2007/2008 and 2008/2009, only 37\% and 22\% of teachers (Note 34), respectively, chose to use the Structural Funds of the European Union (Note 35) and to participate in School-NOPs to strengthen teaching expertise 
on key competences. In addition, there is a tendency to propose initiatives of training to teachers to whom have already been proposed, thus favoring the increasing of differences.

In the school year 2007/2008, the majority of initiatives aimed at teachers focus on the teaching of Scientific Competences in First Cycle Schools. The average age of in-training teachers in the Convergence Objective Regions is relatively young: 41 years old.

The Permanent System of Online Training (SPF) in e-learning mode, is a part of the planned measures to promote expertise development of teachers and trainers in the field of Vocational Education and Training and improve their competences and knowledge. The SPF is a National Project of Continuing Training sponsored by the Ministry of Labor that aims at training and re-training Training Operators, Teachers of Upper Secondary School and Vocational-Technical Institutes and Employment Services Operators (Note 36).

\subsection{Transversal Competences}

How the acquisition of Transversal Key Competences is promoted in Italy?

Education and Training Institutions are increasingly engaging in relationship with local communities and with the world of work. Training Systems establish stable networks in the territories: Schools, Businesses, Chambers of Commerce, School Boards are involved in designing and processing plans for an Integrated Training Offer. The School-Work Activities Monitoring System is entrusted to ANSAS/INDIRE.

The Methodology of Alternation not only allows students to gain an important and meaningful wealth of competences and expertise, to which belong transversal competences in learning to learn and in spirit of initiative and entrepreneurship, but it allows educational institutions to confront and deal with the territory and with the business and economic fabric.

A comparison between years 2005 and 2007/2008 shows a growing participation in internships, apprenticeships and businesses simulated trainings.

Competences acquired by students are recognized with special certificates issued by schools and training institutions in accordance with companies. Learning acquired by students in formal and informal contexts is validated in accordance with the European Qualifications Framework (EQF).

In the construction of the National System of minimum professional standards, of recognition and certification of competences and of educational and training standards the focus on the development of cross-disciplinary competences and on transversal competences is understood as a guarantee of the exercise of professional mobility.

In 1999, Higher Technical Education and Training paths (IFTS) are established to train professionals at a post-secondary level and they respond, in particular, to the demand coming from sectors affected by technological innovations. The aim of these paths is training on basic and transversal competences and providing in-depth and focused technical and vocational training.

In 2002, in order to achieve national uniform levels of competences, the System of Minimum Standards of Basic and Trasversal Competences is approved. Standards are grouped in the Linguistic, Scientific and Technological, Legal, Economic and Corporate and Transversal areas. These competences are the minimum objectives to be achieved at the training paths' conclusion, and they are to demonstrate in the input in case of accreditation processes.

In recent years, the IFTS system is passing through a phase of reorganization:

- in 2008, the IFTS Guidelines are published and the Higher Technical Institutes (ITS) are established;

- in 2012, simplification and promotion measures for Technical and Vocational Education and ITS are adopted and general rules and essential levels of performances for identification and validation of non-formal and informal learning and minimum standards of service of the National System of Certification of Competences are also set out;

- in 2013, the Guidelines for the implementation of 2012 simplification measures are issued.

\subsection{Competences and Evaluation}

How evaluation is used to help pupils and students acquire fundamental and trasversal competences?

In the school year 2007/2008 is realized for the first time, within the state exam in the third year of the first grade of Secondary School (ISCED 2) (Note 37), a National Test on Italian language and Mathematics.

In the school year 2008/2009 is carried out a National Survey addressed to the second and fifth grade of Primary School (ISCED 1) (Note 38), concerning Reading Competences and Comprehension in Native Language (Italian) and Mathematics. 
The evaluation of the Education and Training Offer quality involves an approach based on process and one based on monitoring results. In accordance with the methodological approach outlined in the European Qualifications Framework (EQF), it increases at the national level, the attention given to the acquired learning as an indicator of the Education and Training Systems' quality.

Periodic surveys on evaluation of learning are made in the Education System (INVALSI) (Note 39).

In 2003, within the Vocational Training, is administered to about 1300 students a test on Mathematical Skills, one on Language Skills and a self-assessment on strategic competences. As a result of such testing, to the interested Regions are made available instruments for the assessment of Basic Competences of students coming out of Initial Training.

In the programming period of the Structural Funds 2000-2006, the Ministry of Labor develops a model for evaluating the quality of the Regional Systems of Education and Training. The model defines a set of dimensions and factors that characterize the quality of a Territorial Training System. It proposes a set of indicators and descriptors able to reconstruct and measure the results of the actions proposed/implemented and their compliance and consistency with the expressed demand and the territories' needs.

The model is applied by some North-Central Regions during the final evaluation of the Regional Operational Programs financed by the 2000-2006 European Social Fund. The results of this application show several critical issues regarding the quality of teaching, the capability to build a training design that integrates the Systems of Education and Vocational Training, the achievement of the weakest sections of users. These issues have been taken into account by the Administrations themselves during the preparation of the programming documentation relating to the 2007-2013 European Social Fund.

\subsection{Strategy for Lifelong Learning}

What progress Italy has made in the development and implementation of a consistent and coherent strategy for Lifelong Learning?

The creation of an efficient System of Lifelong Learning is the result of an integrated strategy, that involves:

- a National Level - with the Ministry of Education, The Ministry of Labor, Social Partners, Regions Representatives - in which one works on the political and conceptual level;

- a Regional Level, where Government Systems and Policies are elaborated and experimentation and practical systems of validation of prior learning are promoted.

The work of the Technical Committee for the National Qualifications Framework (NQF) construction begins in 2006 and proceeds in the following years, despite some interruptions due to the requirements dictated by the crisis.

In December 2012, under the State-Regions Conference, the Ministry of Labor, the Ministry of Education, the Regions and the Autonomous Provinces stipulate an Agreement in which they commit to adopt the Report Referencing to the $E Q F$ annexed to that same Agreement and the necessary measures to ensure that, by January 1, 2014, the certifications awarded in Italy report a clear reference to the corresponding EQF level (Note 40).

Table 3 shows for the main qualification types the correspondence with the EQF level and the National Service Provider.

Table 3. Main qualifications associated with EQF level and Issuing Body (State-Regions Conference, 2012).

\begin{tabular}{lll}
\hline EQF LEVEL & QUALIFICATIONS & ISSUED BY \\
\hline 1 & Certificate concluding the First Cycle of Education & MIUR \\
2 & Certificate of basic competences acquired on completion of Compulsory Education & MIUR or Regions \\
3 & Qualification Certificate of Professional Operator & Regions \\
4 & Vocational Diploma of Technician & Regions \\
& High School diploma (including: Technical Education Diploma and Vocational & MIUR \\
& Education Diploma) & Regions \\
5 & Qualification Certificate of Higher Technical Specialization (IFTS) & MIUR \\
7 & Higher Technical Diploma (ITS) & MIUR \\
8 & Degree (first cycle) & MIUR \\
\hline
\end{tabular}

Between 2006 and 2007, on the initiative of the Ministry of Labor the Citizen's Training Booklet is experienced in Trento and Bolzano Provinces and in Friuli Venezia Giulia, Emilia Romagna, Liguria, Molise, Toscana, Valle d'Aosta 
Regions. In April 2008, the Ministry of Labor and ISFOL publish the results of the Trial (Note 41).

With regard to the issue of validation of non-formal and informal learning:

- since many years, the chains of Higher Technical Education and Training (IFTS) and Education of Adults (EDA) have national guidelines for input learning validation;

- in University Courses, competences acquired on the job, through internships or cultural activities, the voluntary sector and the civil service, are recognized

- some Regional Administrations intervene directly on the definition of policies and operational strategies.

In the Booklet of Competences Validation Page, the ISFOL Institute collects documents relating to the most interesting practices of validation of non-formal and informal learning identified within the context of the research Recognition of non-formal and informal learning (Note 42). Such practices can constitute a reference for designing and implementing activities.

The formulation of national standards centered on competences and the reorganization of the Higher Technical Education and Training System (IFTS) occur with reference to the learning outcomes' approach.

In recent years, in order to increase the permeability between Education and Training Systems, the Ministry of Education, the Ministry of Labor and the Regions regulate the following aspects:

- credits assessment methods for the purposes of Second Cycle paths' passages (2003/2005);

- certifications' actions in outbound and inbound (2000/2004);

- regulation of passages from the Vocational Training and Apprenticeship System to the of Vocational Institutions' Classes under the old system with a Recognition of Credits Model (2004);

- procedural rules for the transition from the Vocational Training and Apprenticeship System to the Education System (2004);

- format of certificates and diplomas of Vocational Education and Training and format of competences' certificate for fractions of Vocational Education and Training path (Note 43) (2011).

\subsection{Vocational Education and Training}

What progress Italy has made to enhance the attractiveness of Vocational Education and Training Programs and their responsiveness to the labor market?

Within the three-years' paths of Initial Training aimed at achieving a qualification corresponding to ISCED level 3 (Note 44), the development of the attractiveness is related to the variety of the offer, paths' responsiveness to the territory training needs and the strong polarization on operation.

In the years 2007-2008, a wide Training Offer for the fulfillment of the right-duty to Education and Training is reported. The decomposition of the three-years' courses into several segments and the consideration of different degrees of integration between school and training agencies explain this variety. Besides, several actions for users at a disadvantage are added: courses for those who have not yet obtained the Licenza Media (Note 45) and support courses for those who are struggling to reach the minimum level of competences.

An additional attraction is the local administration of Vocational Training. In effect, a vocational training under the Regions' exclusive competence favors the encounter between Education and Work, which is also achieved through the structuring of courses that provide a substantial hourly rate of job experimentation in real and simulated companies.

Among factors of attraction, it should also be noted the activation of the fourth year of Vocational Training that, after the qualification obtained in the third year, allows the acquisition of a Vocational Diploma of Technician that permits to proceed to Higher-Education paths, and with a supplementary year, to University.

Active methodologies adopted within the three-years' qualification paths make these routes particularly attractive, especially for students who have difficulties working with traditional educational methods.

In recent years, Administrations are committed to make the System of Professional Offer work at full performance under the legal order. To the 2004 State-Regions Agreement follows a trial, carried out by 126 training centers, for the settlement on territory of different offer levels dedicated to one same productive sector characterizing the Local Vocation. It is also referring to this experience that, in 2008, the Guidelines for the Reorganization of the Higher Technical Education and Training System and the Establishment of Higher Technical Institutes (ITS) are issued.

On the base of these Guidelines, each Regional Administration draws up three-years' territorial plans, which articulate the offer of: 
- paths of Higher Technical Education and Training to the exclusive ownership of Regional Administrations, planned on the basis of training needs, related to development of local and national productive fabric;

- paths within Higher Technical Institutes, concerning technological areas identified jointly with the Ministry of Economic Development under the 2015 Industry Plan in support of local production.

The macro goals that the entire segment of Higher Non-Academic Education and Training intends to meet are: ensure training interventions strongly anchored to local needs, provide individualized training, promote and ensure the participation of employed adults, respond to European Qualification Standards.

Currently, the Italian system is much more structured in terms of Higher Non-Academic Education and Training. The reconfiguration of the System is an important step towards supporting the development of the productive fabric made up of small and medium-sized enterprises that alone would have difficulties to support major investments in research and development.

In April 2013, the Interministerial Decree concerning higher technical specializations relating to post-secondary routes of Higher Technical Education and Training lasting one year (IFTS), envisaged by the Decree of 2008, is published.

IFTS paths are planned by Regions; designed and managed by Universities, Second Level Secondary Schools, Public Research Institutes, Accredited Centers and Agencies for Vocational Training and companies or their Associations, associated even in Consortium; refer to manufacturing sectors identified for each three-years' period, in accordance with the Joint Conference. The duration of these paths is of two semesters, and the qualification achieved is the Certificate of Higher Technical Specialization. Main admission qualifications are the High School Diploma and the four years of Vocational Diploma of technician achieved within the Vocational Education and Training System.

The Higher Technical Specializations established are twenty, and they are structured in terms of competences that are common to all figures and in technical-professional competences specific to each figure. The sectors are: agri-food, manufacturing and crafts, mechanical installations and construction, culture, information and information technology, business services, tourism and sport and personal services.

The first application of these learning paths refers to the training year 2013/2014. At the conclusion of which they will be monitored and evaluated for the purpose of making the System work at full performance from 2014/2015.

Interesting is the Telematic Network of Simulated Training Companies Project (IFS) promoted by the Ministry of Education. Schools of all Regions participate in the network experiencing and simulating activities in work situations. In particular, the project provides, for each life stage of the business cycle, a mentoring action by real companies toward virtual companies animated by students. The network is managed by National and Regional Simulation Stations (Note 46).

According to the CVTS (Note 47) Eurostat (Note 48) Survey, in Italy the number of companies investing steadily in training, however, is limited. Despite the start of the Interprofessional Funds, the percentage of companies that receive funding to support Continuing Training Activities corresponds to about $8 \%$. In addition, less than $12 \%$ of the total direct costs are covered by the funding received. Building programs tailored for the needs of small businesses becomes important to increase stable investments in training.

In the framework of the 2000-2006 ESF programming, the Ministry of Labor launches a National System for Permanent Monitoring of Professional and Training Needs. Training requirements, grouped by professions and sectors of economic activity can be matched with employment prospects in a horizon of short and medium term (Note 49).

Within the European Circuit of ENQA-VET (European Network for Quality Assurance in Vocational Education and Training) formed in 2005 and the European Recommendation on Vocational Education and Training Quality, is born the Italian Reference Point (Note 50), with the aim of fostering dialogue and synergies among multiple learning instances and disseminating transnational best practices.

\subsection{Higher Education}

What progress Italy has made to diversify funding sources and foster openness of Higher-Education Institutions to Lifelong Learning?

From 1993 to Universities is given financial autonomy. The main channel of public financing of State Universities is the Ordinary Fund (FFO). The FFO is a state fund that covers the cost of operation and universities' institutional activities and includes resources for the payment of salaries to teachers, researchers and staff. The analysis of the distribution of the main University revenues in the years 2001 and 2006 highlight a decreasing in state funding and an increasing in student and external funding (MIUR, 2009).

The Guidelines for Public Funding to Universities of 2009 refer to a responsible management of public resources, 
University economic and financial recovery and the encouragement of quality and promotion of merit in research and teaching.

Starting from these principles, some priority actions are outlined:

- encourage the adoption of the accounting statement and the balance sheet (Note 51);

- gradually reduce the incidence of staff costs;

- make further restriction on the debt (Note 52);

- not allow calls for new places to the institutions which have exceeded the legal limit in the relationship between fixed allowances (Note 53) and FFO;

- update the current funding model to assign more weight to the quality of teaching and research activity, proven with evaluation;

- on Universities with budgets in deficit, or that do not meet the current law constraints, impose a concrete and rapid plan for the return in standard and arrange for compulsory administration (Note 54) in the event of non-compliance;

- reviewing the relationship between Medical Faculties, Universities and the Health System in order to achieve a balance between functions and costs.

For the year 2013, appropriations for the Ordinary Fund amount to about 7000 million Euro (Note 55).

The birth of the new Bachelor Degree Programs (following the Bologna Model (Note 56)) exercise a great attraction towards occupied adults. People already in the workforce and that in previous years have not completed university studies, find interesting the new Bachelor Programs and enroll, thanks to the recognition mechanism of examinations already passed.

The Annual Reports on the state of University realized by the National Committee For Evaluation (CNVSU) and the Triennial Eurostudent Survey, monitor the phenomenon. According to the data of the Evaluation Committee, in the academic year 2002/2003, the starting year of the new degree programs, $24 \%$ of students enrolling obtained the Diploma di Maturità (Note 57) at least three years before. In recent years, the phenomenon is attenuated, reaching $15 \%$. According to data from Eurostudent, although $80 \%$ of students register within the twenty years of age, $10 \%$ enroll at twenty-five or more.

From the 2012 Report on the implementation of the Bologna Process (Note 58) in European Higher Education we elicit some recent data on Tertiary Education in Italy:

- in the academic year 2008/2009 about 2 million students enroll in Tertiary Education (ISCED levels 5A, 5B, 6) (Note 59);

- comparing the academic year 2003/2004 with 2008/2009, enrollments' increase is of approximately $1 \%$ (10\% is the European average increase);

- Tertiary Education enrollment rate of students with ages ranging between 18 and 34 varies from about $11 \%$ in 1999 , to $12 \%$ in 2004 , to $14 \%$ in 2009.

\subsection{University System (2011 CNVSU Report)}

\subsubsection{Critical Issues}

Other considerations can be elicited from the 2011 CNVSU Report (Note 60). Overall, the Italian University System loses its efficiency and effectiveness. In the period 1990-2010 several critical elements are reported:

- costs per student are high and very variable;

- dropout rates after the first year are high;

- the share of inactive students is high;

- high is the number of student that have not passed all their exams within the prescribed period of time;

- graduation occurs in a long time, and therefore, the university degree is obtained in old age;

- the variability of these factors among the different universities is remarkable.

University reduces its power of attraction: after the academic year 2003/2004 the percentage of nineteen who register continues to decrease. This is due to the reduction in the number of young people obtaining the Diploma di Maturità (Note 61) and in the number of young people who decide to continue their studies. In the academic year 2009/2010 the number of students enrolled at University is less than 300 thousand units. Faced with these results, universities give 
more and more importance to Guidance, to be carried out even before the conclusion of the Second Cycle of Education, and to Mentoring during the years of study at University.

\subsubsection{Services}

From surveys and analyzes on students services, it appears that students rely to Guidance Services on a sporadic basis. This could indicate a lack of awareness of the service potential for medium and long term decisions. Information contained in University Websites are considered to be clear and accessible, but unable to delineate the relationship between Education and Work. It is complained the dissatisfaction with a Tutoring Service done by unqualified persons.

In relation to Scholarships it should be noted:

- the decrease in used funds: $-60 \%$ in 2010 ;

- a relationship eligibility - obtaining at $82 \%$ in 2008/2009;

- a relationship between persons entitled - availability of accommodation at 22\% in 2008/2009.

Against these critical data, in 2008/2009 the number of students pursuing Internships Curricula increases by $10 \%$ and the number of students undertaking a period of study abroad increases by $23 \%$.

\subsubsection{Rationalization}

From the analysis of some processes taking place seems to emerge a rationalization of the Educational Offer (Note 62):

- the number of active courses and operative teachings is reduced,

- the rate of teachings valued four credits $(\mathrm{CFU})$ is reduced and the average value of credit attribution for teaching is increased (six credits in 2008/2009).

In order to verify the validity of the Educational Offer and its efficiency and effectiveness, it is increasingly urgently requested the activation of procedures for courses of study accreditation.

\subsubsection{Process and Outcome}

From the 2010 OECD Statistical Survey Education at a Glance (Note 63) emerges that in Italy, 33\% of students successfully complete a Graduate Program, compared to an OECD average value of 38\%. The 2011 National Evaluation Report, distinguishing outcome indicators and process indicators (Note 64), emphasizes in this regard that:

- students who pass all the exams within the prescribed period of time are $60 \%$, the regularity of studies is decreasing and it is higher in courses with entrance selection trials and access plans;

- drop outs after the first year of University are reduced by one percentage point, standing at 17\% (in 2008/2009)

- the percentage of Inactive Registered (Note 65) increases, reaching $13 \%$

- $\quad$ in 2009 the number of graduates is less than 300 thousand

- the number of First-Level Graduates (Bachelor Degree) decreases (171 thousand in 2009)

- $\quad$ the percentage of students who graduate on time decreases (24\% in 2009).

5.11.5 Careers

Table 4 illustrates the number of units in the various University Positions in 2010 (Table 9).

Table 4 - Value in units and average age of the Teaching Staff in University (MIUR, 2011).

\begin{tabular}{|c|c|c|}
\hline TEACHERS' CAREERS & $\begin{array}{l}\text { UNITS VALUE } \\
\text { in thousand } \\
\text { (ROUND VALUE) }\end{array}$ & $\begin{array}{l}\text { AVERAGE AGE } \\
\text { in years }\end{array}$ \\
\hline $\begin{array}{l}\text { Doctoral Students } \quad(50 \% \text { Temporary Research } \\
\text { Fellows }) \text { (Note 66) }\end{array}$ & 12 & 29 (average age at the entrance) \\
\hline Temporary Research Fellows & 13 & 35 \\
\hline University Researchers & 25 & 45 \\
\hline Associate Professors & 17 & 53 \\
\hline Full Professors & 16 & 60 \\
\hline
\end{tabular}

After the Reform of Public Examination for University Teaching in 1998 (Note 67) and the promotion of merit, a greater 
number of candidates entered in the roles. Furthermore, in recent years the period of service has been lowered. Nevertheless it doesn't seem to be fulfilled one rejuvenation of the teaching body, but rather the natural aging of those who were already in the system.

In addition, there seems not to be input programming in university professorship: the University System is not able to absorb in the roles of Researcher all Doctoral Students and Temporary Research Fellows. These, often of proven scientific value, if not precarious, access to the University System on a permanent basis, in a fairly advanced age.

Between 2000 and 2010, actual exits from the University System, however, are more than double of those for the mere attainment of age limits. In 2010, they exceed three times, and it is estimated that in the 2011-2016 period, more than 14 thousand persons will terminate service. Their distribution, however, could be critical and it's going to exacerbate existing imbalances among different universities and among different subject areas. Therefore, it is stressed the urgent need to develop appropriate strategies and intervention programs.

\subsubsection{Financial Resources and Research}

University System overall revenues, which amount to 13 billion Euro in 2009, are decreasing. Between 2001 and 2009, while funding from students, businesses and institutions increases by $50 \%$, the total impact of funding by the Ministry of Education decreases by $10 \%$.

With regard to the use of resources: the incidence of staff costs on total costs increases, the expenditure for administrative and technical staff decreases, the expenditure for interventions for students significantly increases, infrastructure investment spending decreases further.

In relation to the internal variability of the data, it should be noted that the average contribution per student is more than double in the Universities of the North-West compared to those of the South (1300 Euro/600 Euro).

In the period 2001-2008, the loan amount granted by the MIUR to Research Projects of National Interest (PRIN) decreases by 35 million Euro, turning to 90 million Euro, while the participation in PRIN Tenders increases, both in absolute terms and in terms of overall professors' presence. It also increases the ability of participants to PRIN Calls to obtain a positive verdict. Nevertheless, in the period 2001-2008, the number of financed subjects reduces.

\section{Conclusion}

Of course, the brief considerations expressed herein can in no way be considered conclusive; their only purpose is to try to capture some aspects of the continuous mutation in progress and provide points for discussion, reprocessing and action.

From analysis such as the one carried out so far, frequently emerge systemic critical issues. The European Union, through guidelines and principles that have as a reference a broad view of the whole, encourages everyone to walk the streets that can realize and spread a concrete and full right to citizenship in the twenty-first century.

In the eyes of those that became accustomed to the traditional systems (but never cease to complain about them) the Institution is seen in a bad light: the European Union is perceived as the place of imposed rules and time constraints. By those who already feel social change and the limits of the traditional dynamics, however, the desire to realize is truly shared, and they find a front of alliance and support in the Union acts and in the prospects from which they arise.

Personally, I look at the current turmoil that more and more is gathered within the National System of Education and Training as a creator chaos, essential prerequisite to the achievement of a better and more fruitful balance, where the European Union plays the role of that teacher, sometimes severe and like everyone else, fallible, but that, deep down, we know, prevented us from falling asleep on the books and challenged us to prove our worth.

\section{References}

Alberici, A. (2010). L'educazione degli adulti. Roma: Carocci.

Consiglio dell'Unione Europea. (6 May 2010). Relazione congiunta 2010 del Consiglio e della Commissione sull'attuazione del programma di lavoro "Istruzione e formazione 2010". Gazzetta Ufficiale dell'Unione Europea. Retrieved from http://eur-lex.europa.eu/LexUriServ/LexUriServ.do?uri=OJ:C:2010:117:0001:0007:IT:PDF.

Consiglio dell'Unione Europea. (14 February 2001). Relazione del Consiglio (Istruzione) al Consiglio Europeo "Gli obiettivi futuri e concreti dei sistemi di istruzione $e$ di formazione". Bruxelles. Retrieved from http://ec.europa.eu/education/lifelong-learning-policy/doc/future_it.pdf

Cortini, M. (Ed.). (2008). I mestieri della formazione. Roma: Carocci.

Fioroni, M. (22 August 2007) Decreto Ministeriale no.139. Regolamento recante norme in materia di adempimento dell'obbligo di istruzione. Roma: Ministero dell'istruzione, dell'Università e della Ricerca. Retrieved from 
http://archivio.pubblica.istruzione.it/normativa/2007/dm139_07.shtml

Fioroni, M. (22 August 2007) Decreto Ministeriale no.139. Allegato Documento tecnico. In: Regolamento recante norme in materia di adempimento dell'obbligo di istruzione. Roma: Ministero dell'istruzione, dell'Università e della Ricerca. Retrieved from http://archivio.pubblica.istruzione.it/normativa/2007/allegati/all_dm139new.pdf

Fioroni, M, (22 August 2007) Decreto Ministeriale no.139. Allegato 2 Competenze chiave di cittadinanza da acquisire al termine dell'istruzione obbligatoria. In: Regolamento recante norme in materia di adempimento dell'obbligo di istruzione. Roma: Ministero dell'istruzione, dell'Università e della Ricerca. Retrieved from http://archivio.pubblica.istruzione.it/normativa/2007/allegati/all2_dm139new.pdf

Di Nubila, R.D. (2005). Saper fare formazione. Manuale di metodologia per giovani formatori. Lecce: Pensa Multimedia.

EACEA \& Eurydice \& Eurostat \& Eurostudent. (2012). The European Higher Education Area in 2012: Bologna Process Implementation Report. Education, Audiovisual and Culture Executive Agency. Retrieved from http://epp.eurostat.ec.europa.eu/cache/ITY_OFFPUB/EC-30-12-534/EN/EC-30-12-534-EN.PDF.

ISFOL. (ESF Programming 2000-2006). Guida all'autovalutazione per le strutture scolastiche e formative. Series: I libri del fondo sociale europeo. Retrieved from http://bw5.cilea.it/bw5ne2/ShowFile.aspx?FileName=R2AsBCDdEuk+5t9G5HRnOMPncEgolAb7RIqkExuCCiB ETLC4BZxWD901JQ/CP/do\&SID=ISFLDEFAULThpjhaw55xs130o451vydoejt.

ISFOL. (2013). Le competenze per vivere e lavorare oggi. Principali evidenze dall'Indagine PIAAC. Roma: ISFOL. Retrieved from http://www.isfol.it/pubblicazioni/research-paper/archivio-research-paper/le-competenze-per-vivere-e-lavorare-oggi.

Ministero dell'istruzione, dell'Università e della Ricerca (MIUR) \& Ministero del Lavoro, della Salute e delle Politiche Sociali. (June 2009) Rapporto nazionale 2009 sull'implementazione del programma di lavoro "Istruzione e formazione 2010”. Formazione Orientamento Professionale.

Ministero dell'istruzione, dell'università e della Ricerca (MIUR) \& Comitato Nazionale per la Valutazione del Sistema Universitario. (2011). Undicesimo Rapporto sullo Stato del Sistema Universitario. Retrieved from http://www.cnvsu.it/_library/downloadfile.asp?id=11778

Parlamento Europeo e Consiglio dell'Unione Europea. (30 December 2006). Raccomandazione del Parlamento Europeo e del Consiglio del 18 dicembre 2006 relativa a competenze chiave per l'apprendimento permanente. Gazzetta Ufficiale dell'Unione Europea. Retrieved http://eur-lex.europa.eu/LexUriServ/LexUriServ.do?uri=OJ:L:2006:394:0010:0018:IT:PDF

Savelli, S. (2012). University Course "Metodologie e tecniche della formazione continua". Facoltà di Scienze Politiche. Università degli studi Guglielmo Marconi. Roma.

\section{Notes}

Note 1. For further information on Alberici, A. (2010). L'educazione degli adulti. Roma: Carocci, please refer to: http://www.carocci.it/index.php?option=com_carocci\&task=schedalibro\&Itemid=72\&isbn=9788843022519.

Note 2. See ISFOL (Italian Institute for Development of Workers' Vocational Training) 2011. Quoted in Di Nubila (2005). For further information on Di Nubila, R.D. (2005). Saper fare formazione. Manuale di metodologia per giovani formatori. Lecce: Pensa Multimedia, please refer to: http://www.pensamultimedia.it/pensa/index.php?option=com_virtuemart\&page=shop.product_details\&flypage=flypage _pensa.tpl\&category_id=60\&product_id=416\&Itemid=84\&lang=it

Note 3. See Di Nubila (2005). See Note 2.

Note 4. Including those of G. Le Boterf in the 90s. Quoted in Di Nubila (2005). See Note 2.

Note 5. Including, recently, ISFOL. Quoted in Di Nubila (2005). See Note 2.

Note 6. 1998 Pact for Development and Employment. Quoted in Alberici (2002). See Note 1.

Note 7. Alberici (2002). See Note 1.

Note 8. The European Qualifications Framework (EQF) established in 2008, is a system that allows to compare $E U$ qualifications of Member States' citizens on the basis of the learning outcomes achieved at the end of Education and Training Paths. Certifications, issued by the competent authority, attest the acquisition of competences compatible with the standards set by the National Education System. Starting from 2008, each qualification awarded in Europe can be 
identified by an appropriate EQF level. Retrieved from http://it.wikipedia.org/wiki/Quadro_europeo_delle_qualifiche.

Note 9. The European Union Regional Policy, aims to equate the different levels of development among Regions and Member States in respect to economic, social and territorial cohesion issues. This is realized through the use of Structural Funds (the Social Fund established in 1958 and the Regional Fund established in 1975) and the Cohesion Fund (established in 1994). The budget allocated to Regional Policy represents 35\% of the EU budget and the second item of expenditure. Retrieved from http://europa.eu/legislation_summaries/glossary/structural_cohesion_fund_it.htm.

Note 10. In order to implement the European Community Programming, Member States (or their Regions) propose Operational Programs for the approval of the European Commission. In the period 2007-2013, we refer to the Operational Programs for implementation of National Strategic Plans. Operational Programs are divided into: National Operational Programs, Regional Operational Programs, Interregional Operational Programs. Each plan outlines specific goals referring to a consistent set of priority axes structured on a multi-year basis, to realize which it is allowed to make use of one or more European Structural Funds, as of other financial instruments. Regional Operational Programs are mono-fund and can draw on the European Fund for Regional Development (ERDF) or on the European Social Fund. Retrieved from http://it.wikipedia.org/wiki/Programma_Operativo.

Note 11. These Regions are included in the Convergence Objective, one of the principal objectives for the period 2007-2013, aimed at speeding up convergence of Member States and Regions lagging behind in development, by improving conditions for growth and employment. The Areas of Intervention are: quality of investment in physical and human capital, development of innovation and of a knowledge based society, adaptability to economic and social change, environmental protection, administrative efficiency. The financing is carried out through the European Regional Development Fund, the European Social Fund and the Cohesion Fund. Retrieved from http://it.wikipedia.org/wiki/Fondi_strutturali.

Note 12. Learning (doctrine) and Competences for successful completion of Compulsory Education are related to four main Cultural Axes that make up the fabric for the construction of learning paths directed to the acquisition of key competences. Learning (doctrine) is structured in Skill/Ability and Knowledge, with reference to the description system requested for the adoption of the European Qualifications Framework (EQF). Digital Competence contained in the Axis of Language is common to all axes. Key Competences proposed in Attachment 2 are the result that can be achieved through mutual integration and interdependence between Learning (Doctrine) and Competences contained in the Cultural Axes. M.D. 139/2007.

Note 13. The Italian Guide for Self-Evaluation of Educational and Training Facilities is the Italian version of the guide prepared by the Technical Working Group on Quality, with the support of the CEDEFOP (European Centre for the Development of Vocational Training). For further information please refer to: http://europalavoro.lavoro.gov.it/EuropaLavoro/Varie/Guida-allautovalutazione-per-le-strutture-scolastiche-e-formative.

Note 14. Peer Review is one of the operational tools considered in the National Plan for Quality Assurance responding to the European Recommendation of 18 June 2009. It integrates self-assessment with external evaluation. The Peer Group is composed of teachers or trainers from other schools under the guidance of an Expert. Retrieved from http://www.isfol.it/news/peer-review-dell2019istruzione-e-formazione-professionale.

Note 15. Bilateral Bodies are private entities set up by Trade Unions of Workers and Confederations of Employers in a specific professional category. Retrieved from http://www.ilsole24ore.com/art/SoleOnLine4/100-parole/Diritto/E/Enti-bilaterali.shtml?uuid=ed7b3f86-58b7-11dd-953 4-b5e47a9a4888\&DocRulesView=Libero.

Note 16. Joint Interprofessional Funds finance company training plans, sectoral and regional, that companies, either in single or associated form, decide to realize for their employees. Moreover, they can also fund individual training plans, as well as additional preparatory activities, or anything else relating to training initiatives. If in 2009 these funds involve only Employees, since 2011 they can include workers with Apprenticeship and Fixed Term Contracts. Retrieved from http://www.isfol.it/temi/Formazione_apprendimento/formazione-degli-adulti/fondi-interprofessionali.

Note 17. Collective Labor Agreements arise from the relationship between Trade Unions and Confederations of Employers, with the Government that often acts as a promoter or referee. These contracts set out the parameters and the basic rules to be followed by the Individual Employment Contracts. Retrieved from http://it.wikipedia.org/wiki/Contrattazione_collettiva. Often Corporate Contracts have an integrative function for Collective Agreements, with which they are connected through a Pyramidal Contract System (Articulated Bargaining). For further information on the roles that Supplementary Company Contract please refer to: http://www.studiodicarlo.com/informazioni-professionali/collegamenti-contratti-nazionali.html.

Note 18. For further information on the National Guidelines of the Observatory for Lifelong Learning please refer to: 
http://www.webdesignrieti.it/provrmosservatorio/dispositivo_governance.htm.

Note 19. ANSAS is the Italian acronym for the National Agency for the Development of School Autonomy. The (same) National Institute of Documentation, Innovation and Educational Research (INDIRE) has been restored with the Law 111/2011. For further information on the Institute please refer to: http://www.indire.it/content/index.php?action=istituto.

Note 20. For further information on the National Institute for the Evaluation of the Educational System of Education and Training please refer to: http://www.invalsi.it/invalsi/istituto.php?page=chisiamo.

Note 21. For further information on the Institute for Workers' Training please refer to: http://www.isfol.it/Istituto/chi-siamo.

Note 22. For further information on the RAI please refer to: http://www.rai.it/.

Note 23. The Joint Conference was established in 1997. It consists of the State-Regions' Conference and the City-State and Local Governments' Conference. It aims to foster cooperation between State activities and Local Governments' System, examining matters and tasks of common interest. It is competent in all cases in which the State-Regions' Conference and the City-State and Local Governments' Conference are called upon to speak on the same subject. Retrieved from http://it.wikipedia.org/wiki/Conferenza_unificata.

Note 24. The Regional School Office (USR) is an agency of the Italian Ministry of Education (MIUR) present in 18 Regional Capitals (not present in Valle d'Aosta and Trentino-Alto Adige). It is established in 2000 and it is currently governed by a decree of 2007. It replaces the previous Local Education Authority. Retrieved from http://it.wikipedia.org/wiki/Ufficio_scolastico_regionale. The list of USR is retrieved from http://hubmiur.pubblica.istruzione.it/web/istruzione/usr_index.

Note 25. Since 2008, the Education and Training Offer comprehends the competences required for Compulsory Education fulfillment, including Citizenship Key Competences.

Note 26. These values are rounded.

Note 27. Atypical Workers are regulated by the Legislative Decree no. 276 of 2003. It regulates, in particular: part-time work, administration contracts, intermittent work, job sharing, placement contracts, fixed term work (as a partial replacement of coordinated and continuous collaborations), occasional and accessory services. Retrieved from http://it.wikipedia.org/wiki/Lavoro.

Note 28. In 2006, 51\% of the adult population has successfully completed the Secondary School Cycle, and 13\% achieved a University Education Qualification, compared with a European average of respectively, $70 \%$ and $23 \%$. These values are rounded (Ministero dell'Istruzione \& Ministero del Lavoro, 2009).

Note 29. In 2000, in Lisbon, a program of economic reforms is approved by European Union Heads of State and Government, with the objective expressly stated, to make the European Union the most competitive and dynamic knowledge-based economy by 2010. The Lisbon Strategy opens the way to the Annual Spring European Councils of Heads of State and Government focused on economic and social issues. Retrieved from http://it.wikipedia.org/wiki/Strategia_di_Lisbona.

Note 30. For further information on the PIAAC Programme 2008-2013 and for the first results of the survey conducted in Italy, please refer to: http://europalavoro.lavoro.gov.it/EuropaLavoro/Notizie/1866. For further information on previous surveys like IALS and $A L L$ please refer to: http://www.lesenlireleggere.ch/it/studien_international.cfm.

Note 31. Projects referring to the Action Area Basic Learnings include: M@t.abel (mathematics) $<$ http://www.indire.it/content/index.php?action=read\&id=1439>, $<$ http://www.indire.it/content/index.php?action=read\&id=1299>, ISS (experimental sciences) <http://www.lfns.it/PianoISS/>. Starting from the school year 2009/2010 and for a period of three years, the effectiveness of the Project M@T.Abel is assessed by the INVALSI, starting from the results of students' learning. For the results of the years 2009/2010 please refer to: http://www.invalsi.it/invalsi/ri/matabel/documenti/rapporti/Matabel_0313_Vol1.pdf; $\quad$ http://www.invalsi.it/ invalsi/ri/matabel/documenti/rapporti/Matabel_0313_Vol2.pdf.

Note 32. The OECD (Organization for Economic Cooperation and Development)-PISA (Program for International Student Assessment) surveys are born with the aim of evaluating every three years the level of Education among adolescents in the major industrialized countries. Retrieved from http://it.wikipedia.org/wiki/Programma_per_la_valutazione_internazionale_dell\%27allievo.

Note 33. The IEA (International Association for the Evaluation of Educational Achievement) is an independent association of Educational Research Centers, based in Amsterdam, founded in 1958, in which 53 countries are currently 
participating. The aim of the IEA is to conduct international comparative research in the field of Educational Evaluation. Retrieved from http://www.invalsi.it/invalsi/ric.php?page=intiea. For further information on IEA please refer to: <http://www.iea.nl/>.

Note 34. These are rounded values.

Note 35. See note 9.

Note 36. For further information please refer to Montedoro C. \& Infante V., The Permanent System of Online Education for the Development of Human Resources of the Integrated Training System, Retrieved from http://db.formez.it/ArchivioNews.nsf/be6d2c2ad9825cf8c1256ae800400bc5/847c87bde1d1c973c12572020032b0d9/Te sto/M2/articolo\%2520Montedoro\%2520e\%2520Infante.pdf?OpenElement.

Note 37. It is the Lower Secondary Education or Second Stage of Basic Education, according to the ISCED (International Standard Classification of Education) standard created by UNESCO. Retrieved from http://it.wikipedia.org/wiki/ISCED.

Note 38. It is the Primary Education or First Stage of Basic Education according to the standard ISCED UNESCO. Retrieved from http://it.wikipedia.org/wiki/ISCED.

Note 39. See note 20.

Note 40. For further information on The National Report of referencing to the EQF please refer to: http://hubmiur.pubblica.istruzione.it/web/istruzione/dettaglio news//dettaglioNews/viewDettaglio/24914/11210.

Note 41. For further information on the Trial please refer to http://librettocompetenze.isfol.it/libretto-formativo.html. In December 2013 the Training Booklet is not yet fully operational. Retrieved from http://www.cliclavoro.gov.it/Cittadini/Formazione/Pagine/Il-libretto-formativo.aspx.

Note 42. For further information on the Validation of the Booklet of Competences please refer to: http://librettocompetenze.isfol.it/validazione-delle-competenze.html.

Note 43. For further information on the recognition of the credits obtained in the Paths of Vocational Education and Training for the purpose of the passages in the Education System please refer to: http://www.istruzione.lombardia.gov.it/protlo9720_13/.

Note 44. It is the (Upper) Secondary Education according to the ISCED UNESCO. Retrieved from http://it.wikipedia.org/wiki/ISCED. See also note 37.

Note 45. Previous definition of the qualification obtained at the end of the First Cycle of Education after passing the state exam. For a useful representative scheme of the National School System currently in force please refer to: http://transalp.lavorosenzafrontiere.org/contenuti_it/italia/sist_scolastico_it.htm.

Note 46. For further information on the Telematic Network of Simulated Training Companies Project (IFS) please refer to: http://www.ifsnetwork.it/portale_ifs/content/index.php?action=read_cnt\&id_cnt=6237.

Note 47. CVTS (Continuing Vocational Training Survey) is the first European survey on Continuing Vocational Training carried out by Eurostat in a coordinated manner. Retrieved from http://epp.eurostat.ec.europa.eu/statistics_explained/index.php/Glossary:Continuing_vocational_training_survey_\%28C VTS\%29.

Note 48. The Statistical Office of the European Union (Eurostat) is a General Directorate of the European Commission. Eurostat collects and processes data by Member States for statistical purposes, promoting the process of harmonization of statistical methods. Retrieved from http://it.wikipedia.org/wiki/Eurostat.

Note 49. For further information on the National System for Permanent Monitoring of Professional and Training Needs please refer to: http://archivio.isfol.it/Banche_Dati/Sistema_nazionale_di_osservazione_permanente_dei_fabbisogni_professionali_\%2 8SIS\%29/index.html.

Note 50. For further information on the National Reference Point and the EQAVET Network please refer to: http://www.isfol.it/eqavet.

Note 51. As mentioned in the 2009 National Report, this accounting procedure promotes transparency of financial statements.

Note 52. For further information on The Indicator of Indebtedness of State Universities please refer to: http://attiministeriali.miur.it/anno-2009/settembre/di-01092009-n-90.aspx.

Note 53. It is the fixed allowances for Permanent Staff. 
Note 54. For further details on the Discipline of Financial Distress and Compulsory Administration of University please refer to: http://www.altalex.com/index.php?idnot=16427.

Note 55. For further information on the Ordinary Fund for Universities' Financing please refer to: http://www.camera.it/leg17/1050?appro=910\&Il+Fondo+per+il+finanziamento+ordinario+delle+universit\%C3\%A0.

Note 56. In 1999, twenty-nine European Ministers of Education met in Bologna where they signed the corresponding Declaration, starting an international process of Higher Education Systems' reform. Retrieved from http://it.wikipedia.org/wiki/ Processo_di_Bologna.

Note 57. Previous definition of the qualification obtained at the end of the Second Cycle of Education after passing the state exam. See also note 45.

Note 58. See note 56.

Note 59. It is the First and Second Stage of Tertiary Education according to the standard ISCED UNESCO. Retrieved from http://it.wikipedia.org/wiki/ISCED.

Note 60. For further information on The Eleventh Report of the National Committee on the State of the University System (CNVSU) published in January 2011, please refer to: http://www.cnvsu.it/_library/downloadfile.asp?id 11778. It should be noted that the trends summarized here are based on the average values of the report, and that we accept the statement, often cited in the reference document, of a strong internal variability of each factor/aspect highlighted. It also should be noted that all the values given in the entire text are rounded.

Note 61. See note 57.

Note 62. It seems that this rationalization is mostly attributable to the reduction in the number of teachers. For further information on the possible origins of the rationalization process taking place in the Italian University System, please refer to The Eleventh Report of the National Committee on the State of the University System, available at: http://www.cnvsu.it/_library/downloadfile.asp?id=11778.

Note 63. Quoted in MIUR (2011). For further information on the OECD statistical survey Education at a glance 2010 please refer to: http://www.oecd.org/education/skills beyond school/educationataglance2010oecdindicators.htm.

Note 64. In that regard, it should be noted that the validity of indicators of efficiency in educational processes currently in use is being called into question in relation to their capacity to compare different University contexts (CNVSU, 2011).

Note 65. It is those students who have not given examinations during the year or didn't acquire credits (CNVSU, 2011).

Note 66. 39\% of those who attend a PhD program do not receive any type of financial support (CNVSU, 2011).

Note 67. For further information on the decision-making process of Public Examinations for University Teaching please refer to: http://archivio.lavoce.info/articoli/pagina187.html. For further information on the Law 3 July 1998 no. 210 Rules for the Recruitment of Researchers and University Professors please refer to: http://www.miur.it/0006Menu_C/0012Docume/0098Normat/1612Norme_cf2. htm.

\section{(cc) $\mathrm{Br}$}

This work is licensed under a Creative Commons Attribution 3.0 License. 